\title{
Revitalisasi Penerapan Qanun Nomor 6 Tahun 2014 tentang Hukum Jinayat di Kota Langsa Aceh
}

\author{
Junaidi \\ Muhammad Rusdi bin Muhammadiah \\ Muhazir \\ Fakultas Syariah IAIN Langsa \\ Jl. Merandeh Kota Langsa, Nanggroe Aceh Darussalam \\ E-mail:muhazir@iainlangsa.ac.id
}

\begin{tabular}{llll} 
Submit & $: 13$ November 2019 & Diterima & $:$ 18 Mei 2020 \\
Revisi & $: 03$ April 2020 & Terbit & $:$ 03 Juni 2020 \\
\hline
\end{tabular}

\begin{abstract}
Abstrak: Tulisan ini mengkaji permasalahan penerapan qanun jinayat di Kota Langsa Aceh Darussalam pasca ditetapkannya Qanun Nomor 6 Tahun 2016 tentang Hukum Jinayat, setidaknya ada dua kelompok pro dan kontra terhadap penegakan Qanun Jinayat, kelompok pro menganggap bahwa penegakan Qanun Jinayat sudah bagus sebaliknya kelompok kontra memandang bahwa penegakan Qanun Jinayat tidak optimal dan terkesan tebang pilih, sehingga banyak masyarakat yang merendahkan tugas wilayatul hisbah dan Dinas Syariat Islam. Jenis penelitian ini yaitu nondoktrinal dan pendekatan yang digunakan yaitu pendekatan sosiologis. Teknik pengumpulan data yang digunakan yaitu dengan wawancara dan dokumentasi. Setelah dilakukan penelitian ditemukan bahwa penegakan qanun jinayat di Kota Langsa Aceh belum terlaksana dengan baik. Hal ini disebabkan oleh beberapa faktor, yaitu: (1) substansi hukum yang menunjukan bahwa isi dari qanun jinayat lemah dari aspek perlindungan hukum bagi kaum perempuan sehingga dianggap diskriminasi; (2) struktur hukum yang berkaitan dengan penegak hukum yang dirasakan tidak tegas terhadap pelaku pelanggaran qanun jinayat; (3) budaya kesadaran hukum masyarakat yang rendah sehingga masih terjadi pelanggaran jinayat; (4) moralitas penegak hukum dan kelima, sarana penunjang hukum.
\end{abstract}

Kata Kunci: Qanun, Jinayat, Wilayatul Hisbah, Langsa, Aceh

Abstract: This paper examines the problem of implementing the qanunjinayat in Langsa City Aceh Darussalam after the stipulation of Qanun Number 6 of 2016 concerning Jinayat Law, there are at least two groups of pros and cons to the enforcement of the Qanun Jinayat, the pro groups consider that the enforcement of the Jinayat Qanun is already good otherwise the contra group views that the enforcement of the Jinpu Law Qanun Jinayat is not optimal and seems to be selective, so that many people underestimate the task of wilayatul hisbah and the Islamic Sharia Service. This type of research is non-doctrinal and the approach used is the sociological approach. Data collection techniques used are interviews and documentation. After conducting research it was found that enforcement of qanun jinayat in Langsa City Aceh Darussalam has not been implemented well. This is caused by several factors, namely: (1) the legal substance which shows that the contents of the qanun jinayat in Aceh are weak from the aspect of legal protection for women so that it is considered discrimination; (2) the legal structure relating to law enforcement is felt not to be firm against perpetrators of violations of the qanun jinayat; (3) the culture of legal awareness of the community is low so that jinayat violations still occur; (4) morality of law enforcement and fifth, legal support facilities.

Keywords: Qanun, Jinayat, Wilayatul Hisbah, Langsa, Aceh 


\section{Pendahuluan}

Kehadiran Islam di Aceh membentuk budaya Islam pada setiap aktivitas masyarakat Aceh, dengan menerapkan asas hukum Islam dan hukum adat cukup mewarnai kehidupan budaya masyarakat Aceh, sehingga terjadinya akulturasi antara budaya dan ajaran Islam. ${ }^{1}$ Sebelum Islam berkembang di Aceh, hukum yang berlaku di Aceh adalah hukum adat (customary law) ditambah lagi dengan ragamnya etnis suku di Aceh sehingga membentuk hukum adat yang berbeda-beda, bahkan hingga saat ini dalam Pemerintah juga memberlakukan hukum adat. ${ }^{2}$

Aceh merupakan bagian daerah Indonesia yang terletak di Pulau Sumatera dan merupakan salah satu daerah yang telah menerapkan hukum pidana Islam. Berbeda dengan Provinsi lainya, Aceh menerapkan sanksi hukum Islam bagi pelaku pidana tertentu yang tertuang dalam Qanun Jinayat. Penerapan Qanun Jinayat tidak terlepas dari sejarah perjuangan MoU antara Pemerintah Indonesia dengan masyarakat Aceh. Dengan kata lain, Qanun Jinayat merupakan hasil dari kesepakatan antara pemerintah dengan masyarakat Aceh untuk menjalankan hukum sesuai dengan syariat Islam.

Qanun Jinayat hingga saat ini menjadi bahan perdebatan dalam kajian hukum, karena kehadirannya dianggap sebagai pemicu perpecahan di Indonesia, seakan-akan Aceh merupakan "Negara dalam Negara" karena diakibatkan oleh perbedaan hukum dengan wilayah lain yang ada di Indonesia. Terlepas dari perdebatan tersebut, dengan hadirnya eksistensi Qanun Jinayat di Aceh semakin kuat dengan hadirnya Qanun Nomor 11 Tahun 2002 yang menjelaskan tentang eksistensi syariat Islam dan Qanun Jinayat Nomor 6 Tahun 2014 Tentang Hukum Jinayat semakin mempertegas bahwa Qanun Jinayat di Aceh adalah salah satu sumber hukum dan produk hukum dari sistem hukum di Indonesia. ${ }^{3}$

Berawal dari ketentuan tentang syariat Islam yang telah ditetapkan dalam Undang-Undang Nomor 44 Tahun 1999 menegaskan keistimewaan Provinsi Aceh baik dalam bidang adat, pendidikan, agama dan kebijakan daerah, ditambah lagi dengan kehadiran Undang-Undang Nomor 18 tahun $2001^{4}$ manambah kuat kedudukan qanun di Aceh. Qanun merupakan suatu aturan hukum baik itu bersifat religious maupun kepemerintahan yang dibuat oleh pemerintah untuk dilaksanakan oleh masyarakat, sedangkan untuk perkara jinayat pemerintah Aceh secara khusus mengeluarkan beberapa qanun pada tahun 2003 dan pada akhirnya dilakukan penyempurnaan dengan diterbitkan Qanun Jinayat pada tahun 2014. ${ }^{5}$

Pasca pemberlakuan Qanun Jinayat dimulai pada tahun 2003 sampai saat ini masih banyak terjadi pelanggaran jinayat dan kekerasan, berdasarkan data yang diperoleh dari Jaringan bahwa pada tahun 2013 sebanyak 151 kasus dan pada tahun 2014 berjumlah 205 kasus, secara kuantitatif pelanggaran dan kekerasa meningkat drastis. Di Kota Langsa tingkat pelanggaran Qanun Jinayat pada tahun 2016 terdapat 17 Kasus $^{6}$ dan pada tahun 2018 terdapat 57 kasus. $^{7}$

\footnotetext{
M. B. Hooker, Adat Law in Modern Indonesia, East Asian Historical Monographs (Kuala Lumpur ; New York: Oxford University Press, 1978).6

Darmawan, "Kedudukan Hukum Adat Dalam Otonomi Khusus," KANUN : Jurnal Ilmu Hukum, 2, no. 12 (2010): 334-48.

Zulkarnain Lubis and Bakti Ritonga, Dasar-Dasar Hukum Acara Jinayat (Jakarta: Prenadamedia Group, 2016).6-9

Syarizal Abbas, Maqashid Al-Syariah Dalam Hukum Jinayat Di Aceh (Banda Aceh: Dinas Syariat Islam Aceh, 2015). 15

Dinas Syariat Islam, Hukum Jinayah Dan Hukum Acara Jinayah (Banda Aceh: Naskah Aceh, 2015).x-xi.

"Praktek Hukuman Cambuk Di Aceh Meningkat, Evaluasi Atas Qanun Jinayat Harus Dilakukan Pemerintah _ ICJR.Html," n.d.

"Langsa Tangani 57 Kasus Jinayat - Serambi Indonesia. html," n.d.
} 
Kelemahan dalam pelaksanaan Qanun Jinayat juga berkaitan dengan kepastian hukum tentang proses rehabilitasi terhadap korban, ini menunjukan bahwa pelaksanaan Qanun Jinayat di Aceh belum dapat dijalankan dengan semestinya, karena muatan materil belum komprehensip. Ditambah lagi dengan kasus pemerkosaan yang dilakukan oleh wilayatul hisbah ${ }^{8}$ yang berdampak kepada menurunnya animo masyarakat terhadap penerapan Qanun Jinayat di Kota Langsa Aceh Darussalam. khususnya di bidang jinayat. Belum lagi kasus tentang prostitusi online yang hingga saat ini belum diselesaikan, rentetan kejadian ini akhirnya mendapatkan perlawanan dari masyarakat yang menuntut kepastian hukum. Ditambah lagi banyak perkara jinayat yang berakhir pada peradilan Gampong. Akibatnya Qanun Jinayat hanya sebatas hukum formal yang menjerat bagi mereka yang tidak beruntung tidak dapat menyelesaikan masalah pelanggaran jinayat di tingkat Gampong.

Berdasarkan ragam permasalahan tersebut, maka dibutuhkan berbagai kajian pendekatan dalam membahas permasalahan terkait dengan Qanun Jinayat, baik dari segi penerapan, substansi hukum, Lembaga hukum serta budaya hukum yang diterapkan di masyarakat. permasalahan ini dirasakan perlu pengkajian yang lebih mendalam terkait dengan penerapan Qanun Jinayat dengan mengkaji ulang atau merevitalisasi penerapan Qanun Jinayat di Aceh yang selama ini berjalan apakan sudah sesuai dengan yang diharapkan dan terlebih lagi apakah pelaksanaan qanun selama ini sudah berefek bagi masyarakat Aceh.

\section{Legislasi Qanun Jinayat di Kota Langsa Aceh}

Penamaan Qanun sendiri merujuk kepada kosakata bahasa Arab yang memiliki makna to make law atau role, code yang menunjukan kepada makna hukum, perundang-undangan dan ada juga yang mengartikan bahwa qanun adalah adat dan hasil ijtihad terhadap suatu hukum yang bersumber dari Hukum Islam. ${ }^{9}$ Dapat dipahami bahwa qanun merupakan pemberlakuan hukum yang dihasilkan dari penalaran normative dari sumber-sumber hukum Islam.

Secara substansi qanun berbeda dengan Peraturan Daerah. Akan tetapi, secara formal qanun sama dengan Peraturan Daerah. Pemberlakuan qanun sama seperti pemberlakuan Peraturan Daerah hanya saja penggunaan istilah yang berbeda. Hal ini dapat dilihat pada hierarki sistem hukum Indonesia yang. ${ }^{10}$ Kedudukan Qanun jika dilihat dalam Undang-Undang Nomor 15 Tahun 2019 Tentang Pembentukan Peraturan. Maka, setara dengan Peraturan Daerah. Persamaan tersebut dapat dilihat dari kewenangan dan menetapkan peraturan tersebut, hanya saja substansi dalam Qanun Hukum Jinayat merujuk kepada hukum Islam. ${ }^{11}$

Proses pembentukan qanun di daerah provinsi Aceh sama halnya dengan pembentukan Peraturan Daerah dengan mekanisme peraturan tersebut telah di setujui Gubernur bersama dengan Dewan Perwakilan Daerah/Kota. Mekanisme ini menunjukan bahwa kedudukan qanun dan fungsinya sama dengan Peraturan Daerah sehinga kekuatan mengikatnya juga sama. ${ }^{12}$

\footnotetext{
"Oknum Polisi Syariah Pemerkosa Tahanan Masuk Tahap Penyidikan - Nasional Tempo.Co.Html," n.d.

Muhamud Yunus, Kamus Arab-Indonesia (Jakarta: PT Hidakarya Agung, 1989).357

10 Zaka Firma Aditya and Muhammad Reza Winata, "Rekonstruksi Hierarki Peraturan Perundang-Undangan Di Indonesia (Reconstruction of The Hierarchy of Legislation In Indonesia)," Negara Hukum: Membangun Hukum untuk Keadilan dan Kesejahteraan 9, no. 1 (June 1, 2018), 80

11 Jum Anggriani, “Kedudukan Qanun Dalam Sistem Pemerintahan Daerah Dan Mekanisme Pengawasannya," Jurnal Hukum Ius Quia Iustum 18, no. 3 (2011): 320-35,327

12 Dalinama Telaumbanua, “Undang-Undang Republik Indonesia Nomor 15 Tahun 2019 tentang Perubahan Atas UndangUndang Nomor 12 Tahun 2011 tentang Pembentukan Peraturan Perundang-Undangan,” preprint (Open Science Framework,
} 
Positivisasi syariat Islam di Aceh merupakan langkah awal penguatan hukum Islam dan sistem hukum nasional. Dengan demikain, hukum Islam dapat dipraktikan dalam kehidupan sosial dan semakin memperkuat antusias masyarakat dalam menjalankannya. Dampak yang dihasilkan setelah dilakukan posistivisasi hukum Islam. Maka, kekuatan hukumnya sama dengan hukum Nasional yang bersifat mengikat dan memaksa. Upaya ini tidak akan berjalan ketika hanya sebagai wacana saja, dibutuhkan keseriusan semua elemen masyarakat terutama para legislator dan pemimpin daerah untuk merealisasikanya dalam bentuk Qanun. ${ }^{13}$

Dasar hukum yang menjadi penguat positivisasi syariat Islam saat ini adalah Undang-Undang Nomor 44 Tahun 1999 tentang Penyelenggaraan Keistimewaan Provinsi Daerah Istimewa Aceh. Dalam Undang-undang tersebut menyatakan bahwa keistimewaan yang diperoleh Aceh adalah sebagai bentuk pengakuan Pemerintah terhadap sistem nilai dan adat yang selama ini menjadi bagian dari aktivitas kehidupan masyarakat Aceh. Dalam UUD 1945 juga memberikan ruang kepada daerah yang mempunyai ciri khas untuk memelihara dan mengembangkan kekhasannya di dalam wilayah NKRI.

Berdasarkan Peraturan Daerah Nomor 5 Tahun 2000 tentang Pelaksanaan syariat Islam di Nanggroe Aceh Darussalam. dalam Peraturan Daerah tersebut pada pasal 5 ayat (2) disebutkan bahwa pelaksanaan Syariat Islam meliputi masalah aqidah, ibadah, mu'amalah, akhlah, pendidikan dan

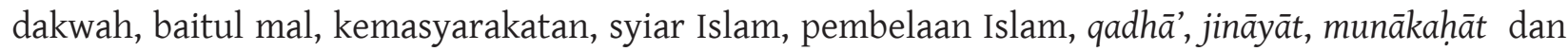
mawaris..$^{14}$ Dapat dicermati bahwa Peraturan Daerah tersebut adalah peraturan pelaksana UndangUndang Nomor 44 Tahun 1999 Tentang keistimewaan Aceh dalam menjalankan syariat Islam. ${ }^{15}$

Ada dua hal penting dalam pemberlakuan keistimewaan aceh, yaitu; Pertama, merupakan penyerahan sebagian urusan Pemerintah Pusat kepada pemerintahan Aceh sehingga sejumlah bidang menjadi otonomi di Aceh (kewenangan pemerintah daerah) lebih luas, dari otonomi yang diberikan kepada provinsi lain. Kedua, merupakan peningkatan kualitas atas otonomi daerah yang memang sudah diberikan kepada semua daerah. Dalam hal ini, otonomi khusus sebenarnya adalah otonomi daerah, tetapi dengan isi dan kualitas yang lebih tinggi. ${ }^{16}$

Pada tahun 2006 pemerintah mengeluarkan Undang-undang yang dikhususkan untuk Aceh yaitu tentang syariat Islam yang tertuang dalam Undang-Undang Nomor 11 Tahun 2006. UndangUndang tersebut mengamanatkan pelaksanaan syariat Islam yang meliputi ibadah, hukum keluarga, Ekonomi Syariah, hukum pidana Islam, peradilan, pendidikan, dakwah, syiar, dan pembelaan Islam. ${ }^{17}$

Undang-undang nomor 11 Tahun 2006 ini menghendaki adanya sejumlah peraturan perundangundangan organik lainnya, terutama Qanun Aceh dalam rangka melaksakan syariat Islam. Qanun berfungsi sebagai peraturan perundang-undangan operasional dalam rangka menjalankan amanat Pemerintah Aceh. Dalam rangka menjadikan hukum syariat sebagai materi hukum positif harus melalui proses legislasi yang menghasilakn Qanun Aceh. Qanun inilah yang akan menjadikan hukum materi dan hukum formil syariat Islam di Aceh. Qanun Aceh merupakan peraturan perundang-

December 2, 2019),

13 Ibnu Hadjar, "Syariat Islam dan Hukum Positif di Indonesia," Al-Mawarid 16 (2006), 11

14 Al Yasa Abubakar, Syari'at Islam Di Provinsi Nanggroe Aceh Darussalam: Paradigma, Kebijakan, Dan Kegiatan (Banda Aceh: Dinas Syariat Islam, 2005). 212

15 Dinas Syariat Islam, Himpunan Undang- Undang, Keputusan Presiden, Peraturan Daerah/ Qanun, Instruksi Gubernur Berkaitan Pelaksanaan Syariat Islam (Banda Aceh: Dinas Syariat Islam Provinsi NAD, 2006). 98

16 Fakhri Ali, Kalla Dan Perdamaian Di Aceh (Jakarta: Lspeu Indonesia, 2008). 227

17 Darmansjah Djumala, Soft Power Untuk Aceh: Resolusi Konflik Dan Politik Desentralisasi (Jakarta: PT Gramedia Pustaka Utama, 2013). 250-252 
undangan sejenis peraturan daerah yang mengatur penyelenggaraan pemerintahan dan kehidupan masyarakat Aceh. Definis qanun ini memberikan pemahaman bahwa qanun di Aceh terdiri atas dua kategori yaitu qanun yang mengatur materi penyelenggaraan pemerintah dan qanun yang mengatur materi penyelenggaraan kehidupan masyarakat Aceh.

Pada era otonomi khusus, Pemerintah Aceh menetapkan qanun jinayat, yaitu: Pertama, Qanun Larangan Khamar dan sejenisnya; Kedua, Qanun Larangan Maisir (judi), dan Ketiga, Qanun Larangan Khalwat, pemberlakuan qanun jinayat tersebut menunjukkan bahwa taqnin jinayat di Aceh sudah mulai dlaksanakan kembali sebagai bentuk dari amanah pelaksanaan syariat Islam yang terkandung dalam Nomor No.18 Tahun 2001.

Secara teoritis daya ikat hukum dikelompokkan menjadi dua yaitu daya ikat bersifat umum dan khusus. Daya ikat bersifat umum di mana daya ikat hukumnya mengikat subyek hukum secara tidak langsung, sedangkan daya ikat khusus mengikat secara langsung semua subjek hukum yang terkait. ${ }^{18}$ Berdasarkan pengelompokan dari daya ikat hukum tersebut, dapat dipahami bahwa Qanun Jinayat merupakan aturan hukum bersifat khusus yang mengikat secara langsung pihak-pihak yang melakukan pelanggaran jinayat.

\section{Penegakan Qanun Nomor 6 Tahun 2014 tentang Hukum Jinayat di Kota Langsa Aceh}

Penegakan qanun tentang hukum jinayat di Kota Langsa Aceh tidak terlepas dari beberapa faktor permasalahan yang mengakibatkan terjadinya pelemahan dalam penegakannya. Adapun beberapa faktor tersebut, ${ }^{19}$ yaitu; Pertama. Faktor penegak hukum; struktur penegak hukum belum optimal dalam mengambil sikap dikarena tergantung dengan anggaran. Apalagi ketika harus dilakukan eksekusi cambuk terhadap pelaku pemerkosaan dan zina. Maka, dibutuhkan biaya untuk sekali eksekusi. Ketika biaya tidak mencukupi akan berdampak kepada melambatnya penegakan qanun jinayat. $^{20}$

Telepas dari permasalahan substansi hukum, permasalahan dalam penegakan qanun jinayat tidak terlepas dari peran masyarakat setempat dalam memberantas pelaku pelanggaran jinayat, proaktif masyarakat turut membantu qanun jinayat berjalan dengan efektif, peran ini tidak dapat diabaikan karena kebanyakan informasi tetang pelanggaran jinayat bersumber dari masyarakat. Namun, terkadang masyarakat memainkan peran di luar kapasitannya sehingga terjadi "main hakim sendiri", tidak sedikit pelaku pelanggaran jinayat mengalami kekerasan sebelum diserahkan kepada pihak yang berwajib dengan dalih sanksi sosial. Terkadang juga kasus-kasus pelanggaran jinayat tidak sampai ke pihak yang berwajib karena diselesaikan di Gampong tempat terjadinya pelanggaran, mengingat di Aceh terdapat peradilan adat Gampong yang mengatur kewenangan perangkat Gampong dalam menyelesaikan perkara-perkara ringan yang terjadi diwilayah yuridiksinya. ${ }^{21}$ Permasalahan ini pernah terjadi di Kota Langsa terkait dengan pelanggarat khalwat dan ikhtilath di mana pelaku dibebaskan dengan membayar denda kepada Gampong. ${ }^{22}$

\footnotetext{
18 Jimly Asshiddiqie, Perihal undang-undang (Jakarta: Rajawali Pers, 2010). 130

19 Ibrahim Latif, Kepala Dinas Syariat Islam Kota Langsa, Wawancara, 09 Agustus 2019, n.d.

20 Zulkarnai, Ketua Majelis Pemusyawaratan Ulama Kota langsa, Wawancara, 12 Agustus 2019

${ }_{21}$ Taqwaddin Husin, "Penyelesaian Sengketa/Perselisihan Secara Adat Gampong di Aceh," Kanun Jurnal Ilmu Hukum, no. 67 (2015): 22., 512-532

22 Amir Hamzah, Penyuluh Keagamaan Kota Langsa, wawancara, 13 Agustus 2019, n.d.
} 
Kewenangan peradilan adat di Aceh didukung oleh sejumlah peraturan perundang-undangan. Dalam berbagai peraturan perundang-undangan tersebut dinyatakan secara tegas bahwa penguatan hukum adat dan peradilan adat harus dimulai dari Gampong dan Mukim. Adapun badan-badan resmi yang menyelenggarakan peradilan adat yaitu Lembaga Gampong dan Lembaga Mukim. Secara hirarki kronologis dasar hukum peradilan adat antara lain:

1. Diatur dalam Undang-Undang Nomor 11 Tahun 2006 tentang Pemerintahan Aceh, Pasal 98 ayat (2) mengatakan bahwa penyelesaian masalah sosial kemasyarakatan secara adat ditempuh melalui Lembaga Adat.

2. Diatur dalam Qanun Propinsi Nanggroe Aceh Darusslaam Nomor 4 Tahun 2003 tentang Pemerintahan Mukim memberikan wewenang kepada Mukim untuk:
a) Memutuskan dan atau menetapkan hukum
b) Memelihara dan mengembangkan adat
c) Menyelenggarakan perdamaian adat
d) Menyelesaikan dan memberikan keputusan-keputusan adat terhadap perselisihan- perselisihan dna pelanggaran adat
e) Memberikan kekuatan hukum terhadap sesuatu hal dan pembuktian lainnya menurut adat
f) Menyelesaikan perkara-perkara yang berhubungan dengan adat dan adat istiadat.

3. Qanun Provinsi Nanggroe Aceh Darussalam Nomor 5 Tahun 2003 tentang Pemerintahan Gampong, menegaskan bahwa tugas dan kewajiban pemerintahan Gampong adalah:
a) Menyelesiakan sengketa adat
b) Menjaga dan memelihara kelestarian adat dan istiadat
c) Memelihara ketentraman dan ketertiban serta mencegah munculnya perbuatan maksiat dalam masyarakat
d) Bersama dengan Tuha Peut dan Imum Meunasah menjadi hakim perdamaian.

4. Qanun Aceh Nomor 9 Tahun 2008 Tentang Pembinaan Kehidupan Adat dan Adat Istiadat pada Ketentuan Umum Pasal 1 angka 10 menyeutkan bahwa adat adalah aturan perbuatan dan kebiasaan yang telah berlaku dalam masyarakat yang dijadikan pedoman dalam pergaulan hidup di Aceh. Dalam angka 11 nya menyebutkan Hukum Adat adalah seperangkat ketentuan tidak tertulis yang hidup dan berkembang dalam masyarakat Aceh, yang memiliki sanksi apabila dilanggar.

5. Qanun Aceh Nomor 10 Tanun 2008 tentang Lembaga Adat pada Ketentuan Umum Pasal 1 angka 9 menyebutkan Lembaga Adat adalah suatu organisasi kemasyarakatan adat yang dibentuk oleh suatu masyarakat hukum adat tertentu mempunyai wilayah tertentu dan mempunyai harta kekayaan tersendiri serta berhak dan berwenang untuk mengatur dan mengurus serta menyelesaikan hal-hal yang berkaitan dengan adat Aceh.

6. Peraturan Gubernur Aceh Nomor 25 Tahun 2011 tentang Pedoman Umum Penyelenggaraan Pemerintahan Gampong Pasal 1 Angka 18 disebutkan bahwa Lembaga Adat adalah suatu organisasi kemasyarakatan adat yang dibentuk oleh suatu masyarakat hukum adat tertentu dan mempunyai harta kekayaan tersendiri serta berhak dan berwenang untuk mengatur dan mengurus serta menyelesaikan hal-hal yang berkaitan dengan adat Aceh. 
Dalam Pasal 5 juga disebutkan pedoman umum penyelenggaraan pemerintahan Gampong, salah satunya adalah penyelesaian sengketa menurut penyelenggaraan pemerintahan Gampong, salah satunya adalah penyelesaian sengketa menurut hukum adat. Dalam Lampiran Peraturan Gubernur tersebut juga menjelaskan bahwa salah satu tugas Tuha Peut Gampong adalah menyelesaikan sengketa yang timbul dalam masyarakat bersama geuchik dan pemangku adat.

Surat Keputusan Bersama Gubernur Aceh, Kapolda Aceh dan Ketua Majelis Adat Aceh Nomor: 198/677/2011/No:1054/MAA/XII/2011/No:B/121/I/2012 tentang Penyelenggaraan Peradilan Adat Gampong dan Mukim atau nama lain di Aceh, mengeluarkan keputusan diantaranya:

1. Sengketa/perselisihan yang terjadi ditingkat gampong dna mukim yang bersifat ringan sebagaimana diatur dalam Pasal 13, 14, 15 Qanun No. 9 Tahun 2008 wajib diselesaikan terlebih dahulu melalui Peradilan Adat Gampong dan Mukim.

2. Aparat kepolisian memberikan kesempatan agar setiap sengketa/perselisihan sebagaimana dimaksud pada point ke satu untuk diselesaikan terlebih dahulu melalui Peradilan Adat gampong atau mukim.

3. Semua pihak wajib menghormati penyelenggaraan Peradilan adat Gampong dan Mukim.

4. Peradilan Adat Gampong atau Mukim dalam penyelesaiannyadapat member putusan berdasarkan pada norma hukum adat dan adat istiadat yang berlaku di daerah setempat.

5. Persidangan Peradilan Adat Gampong dan Mukim dihadiri oleh para pihak, saksi-saksi dan terbuka untuk umum, kecuali untuk kasus-kasus tertentu yang menurut adat dan kepatutan tidka boleh terbuka untuk umum.

6. Putusan Peradilan Adat Gampong dan Mukim bersifat final dan mengikat serta tidak dapat diajukan lagi pada peradilan umum atau peradilan lainnya.

7. Setiap peradilan adat gampong dan mukim dibuat secara tertulis, ditandatangani oleh ketua dan anggota majelis serta kedua belah pihak yang bersengketa dan tembusannya disampaikan kepada Kapolsek, Camat serta MAA Kecamatan.

Ketika terjadinya permasalahan di Gampong. Maka, tokoh adat memiliki peran untuk menyelesaikannya pada Peradilan adat. Peradilan adat merupakan peradilan perdamaaian yang memiliki tujuan untuk mendamaikan atau mencari solusi dari permasalahan yang terjadi di masyarakat, sehingga tidak perlu lagi diselesaikan di Pengadilan. ${ }^{23}$

Dalam kajian sistem hukum beberapa hal penting yang membutuhkan perhatian khusus dalam

\footnotetext{
3 Ahmad Ubbe, "Peradilan Adat Dan Keadilan Restoratif," Jurnal Rechts Vinding 2, no. 2 (2013): 15brotherhood and efforts to restore order and peace in accordance to the community awareness of law. Indonesia has various cultural repertoire of social and legal systems of courts, judges and justice. This paper raises the issue of how to form penal mediation and protection of victims in restorative justice system; overview on how customary law and justice in Indonesia; how alternative dispute resolution and restorative justice in customary law; as well as how to handle violations of Indigenous and penal mediation in customary law. By using normative methods can be concluded that the customary justice become important in the national law system. Therefore, it is necessary to transform the customary law values that live in the community, like the law, justice, judge, and equity, as a part of the national law system. This effort is important in order to end the dichotomy between the institutions and ideas of \"state law $\backslash$ " and \"folk law \". Implementation of restorative justice method is important to be the theoretical and philosophical bridge, to make the legal values that live in the community, as a basis for the development and the proper functioning of the legitimacy of customs law, justice and judges, in fairness distribution.","container-title":"Jurnal Rechts Vinding","issue":"2","language":"id","page":"15","source":"Zotero","title":"PERADILAN ADAT DAN KEADILAN REST ORATIF","volume":"2","author":[\{“family":"Ubbe","given":"Ahmad"\}],"issued”:\{“date-parts":[[“2013”]]\}\}\}],"schema":"htt ps://github.com/citation-style-language/schema/raw/master/csl-citation.json"\} , 161-175
} 
pelaksanaan hukum agar dapat terlaksana dengan baik setidaknya ada tiga (3) poin besar yaitu pertama, komponen strutural, yaitu bagian yang bergerak dalam suatu mekanisme (lembaga). Dalam pelaksanaan qanun jinayat masih memiliki kelemahan dalam penegakan hukum seolah-olah hukum tumpul keatas dan tajam ke bawah, kesan ini dirasakan karena kasus yang terjaring oleh Dinas Syariat Islam atau wilayatul hisbah rata-rata masyarakat menengah kebawah dan belum menyentuh pihak-pihak menengah keatas, agar penerapan qanun jinayat dibutuhkan penguatan mendukung kewenangan yang utuh bagi Dinas Syariat Islam dan wilayatul hisbah, bukan tidak mungkin wilayatul hisbah dipersenjatai agar memiliki wibawa.

Kelemahan lain dalam lain yaitu pada wilayatul hisbah hingga saat ini belum ada kejelasan tentang status wilayatul hisbah dalam system hukum di Indonesia khususnya di Aceh, karena mayoritas dari mereka adalah tenaga kontrak dan PNS sehingga kewenangan dalam penegakan hukum tidak jelas, karena satu sisi melekat dengan aturan PNS dan satu sisi melekat dengan aturan pemerintahan Kota Langsa, hingga terbitnya UUPA Tahun 2006 pada undang-undang ini wilayatul hisbah disatukan dengan Satpol PP perbedaannya bahwa secara status wilayatul hisbah sama dengan Satpol PP, namun secara kelembagaan melekat kepada Dinas Syariat Islam, ini semakin mempersulit kerjanya sehingga dalam penegakan qanun jinayat wilayatul hisbah masih lemah.

Kedua, faktor substansial hukum. Ada beberapa aturan yang dirasakan sangat diskriminasi terhadap kaum wanita misalnya tentang wanita korban pemerkosaan apabila ingin melapor kepihak yang berwajib maka disyaratkan untuk memiliki 4 alat bukti dan apa bila tidak ditemukan alat bukti, cukup dengan sumpah. Apabila pelaku ikut bersumpah maka ia bebas dari jeratan hukum. Pembuktian ini sekilas seperti kasus Qadzaf (menuduh seseorang berzina), seyogyanya pemerintah Kota Langsa juga memikirkan bagaimana problem psikologis yang dihadapi oleh wanita korban perkosaan, ini menunjukan bahwa perlindungan bagi kaum wanita lemah.

Di sisi lain, Qanun jinayat juga mengatur tentang hukum qadzaf yang apabila tidak memiliki alat bukti maka cukup dengan bersumpah satu sama lainnya, sehingga sumpah dapat menjadi suatu tameng untuk pihak pelaku/terduga lepas dari jeratan hukum, bahkan apa bila penuduh qadzaf tidak dapat membuktikan dianggap dialah pelaku Qadzaf dan dapat dikenakan sanksi hukuman yang terbilang berat sekali ada dua bentuk hukumannya yaitu uqubat ta'zir sebanyak 400 gram emas murni dan hudud sebanyak 80 kali cambuk. Terlihat bahwa bentuk sanksi yang diterapkan dalam Qanun Jinayat sangat berbeda sekali dengan KUHP yang berlaku di Indonesia, bentuk hukum yang ditawarkan oleh Qanun Jinayat berupa hudud, ta'zir yang kesemua itu tergantung kepada Mahkamah Syar'iyah yang memiliki kewenangan dalam mengadili kasus pelanggaran Jinayat.

Salah satu pinsip dasar penerapan Qanun Jinayat sendiri menciptakan keadilan dan keseimbangan dengan tidak menafikan hak-hak asasi manusia. Harapan besar dari qanun tersebut adalah terciptanya sosial masyarakat yang berpegang teguh kepada prinsip-prinsip keislaman, di sisi lain dalam qanun jinayat tidak menepis dari kajian pendekatan gender. Akan tetapi, isi dari qanun tersebut dinilai oleh aktivis perempuan mendiskriminasikan kaum perempuan.

Permasalahan substansi hukum juga berkaitan dengan kejelasan rehabilitasi terutama bagi korban pemerkosaan, hingga saat ini belum diatur bagaimana proses dan ketentuan perlindungan atau rehabilitasi bagi korban pemerkosaan. Dalam qanun jinayat aturan tentang pemerkosaan diatur dalam Pasal 48, 49, 50 dan 51 yang hanya mengatur tentang sanksi bagi pelaku pemerkosa, tetapi tidak untuk korban pemerkosaan, untuk biaya meteril yang merugikan korban dibebankan 
kepada pelaku sebesar 750 gram emas murni. Kondisi ini menurut peneliti tidak mengandung aspek kepastian hukum ketika "kerugian" dibebankan kepada pelaku, tidak ada kejelasan hukum apabila pelaku tidak mampu memberikan kerugian terhadap korban. Seyogyanya pemerintah perlu mengambil sikap tegas demi terciptanya kepastian hukum dan jaminan sosial baik psikis maupun materil, apalagi ketika korban merupakan anak di bawah umur maka membutuhkan perhatian khusus dari pemerintah sebagaimana kasus akhir-akhir ini yang dialami oleh anak dibawah umur yang diperkosa oleh ayahnya sendiri, tentu perbuatan keji tersebut setidaknya mendapat sanksi hukum yang setimpal dan bagi korbannya seyogyanya mendapatkan perlindungan dan perhatian khusus dari pemerintah.

Ketiga, faktor kesadaran hukum, ${ }^{24}$ hal terpenting dalam penegakan hukum yaitu tentang kesadaran hukum karena ini berkaitan langsung dengan pihak yang diatur, seperti yang telah diuraikan sebelumnya bahwa hukum itu dibuat karena dibutuhkan untuk mengatur tatanan sosial masyarakat, sebesar apapun sanksi hukum apabila tidak ditaati dan dijalankan maka hukum tidak akan terlaksanan dengan baik. Agar masyarakat patuh terhadap hukum maka diperlukan beberapa indikator antara lain:25
a. Pengetahuan hukum;
b. Pengetahuan tentang substansi hukum;
c. Etika terhadap hukum;
d. Perilaku hukum.

Poin tersebut di atas menurut Soerjono Soekanto merupakan pola penting dalam menumbuhkan sikap kepedulian terhadap hukum, tentunya memang kepedulian terhadap hukum di Indonesia khususnya di Kota Langsa Aceh terhadap qanun jinayat masih kurang, karena memang aturan yang mengatur perihal "jiwa” seseorang itu sulit sekali untuk di terapkan, seperti halnya khalwat, permasalahan khalwat merupakan bagian dari syahwat yang berhubungan langsung dengan jiwa individu. ${ }^{26}$

Untuk meningkatkan ketaatan masyarakat terhadap hukum yang berkaitan dengan sikap individu, Islam menawarkan beberapa hal yaitu; a) Pengetahuan. b), Keimanan. c), Dampak negative. d), Sanksi hukum sebagai pengikat. e). Reward. Kelima langkah ini penting diperhatikan dalam penegakan hukum akan tetapi untuk merangsang kepatuhan hukum masyarakat penting juga diberikan reward terhadap masyarakat yang berkontribusi langsung dalam penegakan qanun jinayat.

Kempat, kurangnya hiburan, ${ }^{27}$ ditengah hiruk-pikuk aktivitas masyarakat hiburan menjadi hal yang sangat penting dalam menciptakan pikiran yang sehat, sehingga masyarakat tidak mencari hiburan yang memungkinkan bertentangan dengan qanun jinayat. Faktanya memang Kota Langsa terbatas dalam mengakses tempat hubiran akibatnya para pemuda dan pemudi baik tua dan muda menjadikan judi online, keybord, khalwat, ikhtilath dan lainya sebagai bentuk hiburan, dalam Islam sendiri menegaskan bahwa pentingnya hiburan untuk refresh pikiran dari aktivitas yang padat.

Kelima, masyarakat yang homogen, masyarakat Kota Langsa merupakan masyarakat yang

\footnotetext{
24 Latif, Kepala Dinas Syariat Islam Kota Langsa, Wawancara, 09 Agustus 2019.

25 Atang Hermawan Usman, "Kesadaran Hukum Masyarakat Dan Pemerintah Sebagai Faktor Tegaknya Negara Hukum Di Indonesia," Jurnal Wawasan Hukum 30, no. 1 (2014): 28. 26-53

26 Soerjono Soekanto, Kegunaan Sosiologi Hukum Bagi Kalangan Hukum (Bandung: PT. Citra Aditya Bakti, 1989), 140

27 Latif, Kepala Dinas Syariat Islam Kota Langsa, Wawancara, 09 Agustus 2019.
} 


\section{يl'Manāhij}

homogen karena rata-rata merupakan pendatang dari berbagai daerah dan dari luar Aceh yang tidak terbiasa dengan qanun jinayat, akibatnya sering terjadi pelanggaran karena faktor latar belakangyang dibawa oleh masing-masing individu untuk menetap di Aceh. Menurut data Statitik Pemerintahan Kota Langsa menunjukan bahwa ada beberapa suku yang menetap di Kota Langsa antara lain suku Aceh, Melayu, Jawa, Tionghua, Batak dan Bugis. percampuran berbagai macam suku yang datang dari luar daerah juga turut mempengaruhi proses berjalannya qanun jinayat.

Keenam, faktor budaya hukum, kita mengetahui bahwa budaya hukum Indonesia sangat buruk kerena dilatarbelakangi oleh lingkungan, hukum dan penegak hukum tidak terkoneksikan sehingga mengakibatkan hukum berjalan sendiri. Budaya hukum berkaitan erat dengan kesadaran hukum yang mana menuntut masyarakat untuk mematuhi aturan yang telah di buat. Dalam dimensi kehidupan masyarakat aspek budaya merupakan nilai-nilai yang tertanam dalam kehidupan seharihari dan tidak disadari bahwa nilai yang tumbuh dengan penguatan budaya memiliki efek besar dalam penegakan hukum, seyogyanya budaya memiliki peranan penting dalam merumuskan aturan hukum karena budaya merupakan norma hukum dasar yang juga diatur dalam UUD 1945.

Lawrence M. Friedmen dalam merumuskan teori sistem hukum cukup memperhatikan pentingnya budaya hukum dalam penegakan hukum. Nilai-nilai dalam budaya juga sangat mempengaruhi terhadap penggunaan hukum, sehingga budaya sangat penting dalam menciptakan keteraturan hukum. Friedmen melihat bahwa budaya hukum merupakan nilai normatif yang hadir dari nilai-nilai dasar dalam masyarakat dan sulit untuk dipisahkan karena itu sudah menyatu dengan kesadaran individu. ${ }^{28}$

Untuk menciptakan budaya hukum yang baik agar hukum menjadi living law bagi setiap masyarakat. Maka, dibutuhkan beberapa metode antara lain; Pertama, pembinaan hukum, diperlukan pembinaan hukum tentang qanun jinayat bagi masyarakat agar memahami pesan yang terkandung dalam aturan tersebut serta memberikan informasi dampak yang akan diterima ketika pelanggara tersebut dilakukan dampak tersebut baik bersifat teologis maupun praktis. Kedua, adanya role model yang menjadi acuan atau panutan bagi masyarakat untuk menggugah semangat masyarakat mentaati aturan hukum yang telah dibuat. Ketiga, sosialisasi hukum (fiksi hukum) pola ini dengan melibatkan masyarakat dalam mensosialisasikan qanun jinayat dengan menciptakan pergerakan atau icon yang mendukung penegakan qanun jinayat. Keempat, ketegasan penegakan hukum, pola ini sangat penting bagi para penegak hukum untuk membentuk karakter hukum atau budaya hukum di kalangan masyarakat sesuai dengan apa yang dikatakan Roscoe Pound dalam Satcipto Rahardjo bahwa fungsi dari hukum itu adalah menciptakan budaya baru bagi masyarakat dengan mempertimbangkan nilainilai yang hidup dalam masyarakat. ${ }^{29}$

Efektifitas suatu hukum dinilai dari lima aspek sebagaimana yang diutarakan oleh Soerjono Soekanto, ${ }^{30}$ yaitu; Pertama, aturan hukum itu senditi, maksudnya yaitu kejelasan dan keserasian antara peraturan yang telah ada. Kedua, sarana dan pra-sarana dalam menunjang penegakan hukum karena tanpa adanya sarana dan pra-sarana hukum tidak dapat ditegakkan. Dalam hal ini dalam penegakan qanun jinayat diperlukan dana setiap melakukan razia. Dinas Syariat Islam membutuhkan dana lebih

\footnotetext{
${ }_{28}$ Lawrence M. Friedman, The Legal System: A Social Science Perspective, trans. M. Khozim, 5th ed. (Bandung: Nusa Media, 2013), 17-18

29 Satjipto Rahardjo, Hukum Dan Perubahan Sosial: Suatu Tinjauan Teoretis Serta Pengalaman-Pengalaman Di Indonesia, Cet. 3 (Yogyakarta: Genta Pub, 2009), 134

30 Soerjono Soekanto, Faktor-Faktor Yang Mempengaruhi Penegakan Hukum (Jakarta: PT. Raja Grafindo Persada, 2008),8
} 
untuk biaya akomodasi. Oleh karena itu, sarana dan pra-sarana menjadi hal yang terpenting dalam penegakan hukum. Ketiga, kesadaran hukum yang timbul dari masyarakat terhadap qanun jinayat, ketika tumbuh kesadaran tersebut maka dengan tidak sadar masyarakat akan patuh dan qanun jinayat menjadi melekat dalam kehidupan masyarakat. Keempat, Mental aparat penegak hukum, penegakan hukum juga sangat tergantung kepada mental dari aparat hukum, kerena ditangan merekalah hukum itu dapat berjalan dengan baik, disamping itu dibutuhkan mental yang kuat dalam menindak pelaku pelanggaran jinayat tanpa pandang bulu. Kelima, budaya hukum, dengan berkurangnya pelanggaran qanun jinayat berarti budaya patuh terhadap hukum semakin baik. Efektifitas bukan dilihat dari keberhasilan wilayatul hisbah dan pihak terkait dalam menangkap pelaku pelanggaran akan tetapi efektifitas dilihat dari menurunnya pelaku pelanggaran.

\section{Strategi dalam Penegakan Qanun Jinayat di Kota Langsa Aceh Darussalam}

Dibutuhkan beberapa strategi yang dapat ditempuh oleh pemerintah dalam merevitalisasi penegakan qanun jinayat di Kota Langsa Aceh Darussalam:

Pertama, memberikan kewenangan yang lebih luas terhadap kinerja wilayatul hisbah. Kewenangan yang dimiliki wilayatul hisbah selama ini hanya sebatas melakukan pengawasan terhadap penegakan syariat Islam sekaligus melakukan pembinaan terhadap para pelanggar Qanun jinayat yang berlaku di Aceh. Sedangkan untuk penindakan dan eksekusi sepenuhnya dilimpahkan kepada Kepolisian dan Kejaksaan. Adanya dualisme lembaga dalam penyelesaian pelanggaran qanun jinayat ini merupakan kendala tersendiri bagi wilayatul hisbah dalam menegakkan Qanun Jinayat. Kewenangan yang besar memungkinkan Wiyatul Hisbah menjalankan fungsinya dengan baik. Apabila fungsi telah dijalankan dengan baik oleh wilayatul hisbah, maka efektivitas penegakan Qanun Jinayat pun akan semakin baik.

Kedua, peningkatan SDM wilayatul hisbah. Peningkatan SDM sangat penting dalam penegakan syariat di Kota Langsa. Oleh karena itu, setiap anggota wilayatul hisbah dituntut untuk memiliki kecakapan dalam bidang Hukum Islam. Inilah yang menjadi kendala selama ini, di mana masyarakat menilai wilayatul hisbah di Kota Langsa belum layak untuk dijadikan sebagai penegak qanun jinayat. Hal ini berkaitan dengan moralitas dan kecakapan para personil wilayatul hisbah yang dianggap selama ini masih kurang. Perekrutan anggota wilayatul hisbah yang berlatar belakang pendidikan agama dirasa sangat diperlukan untuk menjawab keresahan masyarakat selama ini. Tidak hanya itu saja, perlu ditingkatkan SDM wilayatul hisbah dalam memahami ketentuan hukum yang berkaitan dengan hukum perdata, pidana, jinayat, acara pidana dan keilmuan lainnya yang dibutuhkan.

Ketiga, meningkatkan kesadaran hukum masyarakat terhadap qanun jinayat. Kesadaran hukum yang masih rendah dari kalangan masyarakat selama ini menjadi salah satu faktor yang juga menghambat penegakan qanun jinayat secara efektif. Kondisi sosial kemasyarakatan Kota Langsa sebelum diberlakukannya qanun jinayat ini menjadi alasan utama. Peneliti sendiri melihat perlu bagi Dinas Syariat Islam dan Wilayatul hisbah dapat meningkatkan hubungannya dengan masyarakat dan khususnya para tokoh masyarakat secara intens disetiap gampong yang ada, serta menjadikan mereka sebagai salah satu unsur pengawas utama setiap qanun di gampongnya masing-masing. Hal ini dikarenakan para tokoh masyarakat gampong pada dasarnya sangat disegani oleh setiap warganya, dan para pelaku pelanggaran Qanun jinayat ini diharapkan akan berpkir berulangkali ketika hendak 


\section{시-Manāhij}

melakukan pelanggaran.

Keempat, meningkatkan sarana dan pra-sarana demi menunjang penegakan qanun jinayat karena masalah ini rentan sekali dalam mempengaruhi terlaksanaanya qanun jinayat di Kota Langsa.

Kelima, kerjasama dengan pengusaha peyedia jasa layanan. Pelanggaran qanun jinayat di Kota Langsa ini sangat rentan terjadi di hotel (penginapan) dan caffee dan pusat hiburan yang ada. Banyaknya fasilitas seperti karaoke di tempat-tempat tersebut menjadi kendala tersendiri dalam penegakan Qanun Jinayat yang efektif. Berkumpulnya pemuda-pemudi yang bukan mahram diberbagai cafe sampai larut malam juga menjadi pemandangan yang lumrah di Kota Langsa. Apabila hal ini dibiarkan begitu saja setiap hari, maka dipastikan penegakan Qanun jinayat akan menjadi tidak efektif di Kota Langsa.

Keenam, menghidupkan seluruh masjid guna untuk memberikan edukasi terhadap masyarakat tentang dampak dan fungsi dari penegakan sanksi hokum jinayat di Kota Langsa selain itu juga dibutuhkan role model yang menjadi contoh bagi warganya untuk meneladani sosok pemimpin yang memberikan cotoh terhadap qanun jinayat.

Kedelapan, kepastian dan kejelasan hukum, hal ini dimaksud untuk mempertegas bagi pelanggaran qanun jinayat yang tidak melihat status sosial masing-masing apakah dia pejabat atau keluarga pejabat sehingga masyarakat tidak memandang remeh penerapan qanun jinayat. Selain itu, kepastian hukum akan membentuk budaya masyarakat taat hukum. Problem besar dari penegakan Qanun Jinayat adalah kejelasan dan kepastian hukum baik berkaitan dengan susbtansi hukum dan keadilan dalam penegakan hukum.

Pola penting yang perlu dibangun terutama adalah kesadaran hukum masyarakat Kota Langsa terhadap qanun jinayat, pendekatan-pendakatan yang dapat dilakukan selain dengan substansi dan struktur hukum adalah dengan pendekatan religious, karena qanun merupakan reduksi dari ajaran Islam yang bertujuan untuk menciptakan tatanan kehidupan yang lebih teratur dan bermoral.

\section{Penutup}

Penegakan qanun jinayat di Kota Langsa Aceh Darussalam tidak terlepas dari berbagai permasalahan, baik itu dari aspek substansi, budaya, moralitas, sarana dan struktur (lembaga penegak hukum). Bahkan, dalam pelaksanaanya sering mendapatkan perlawanan dari masyarakat. Perlu dilakukan revitalisasi dalam penegakan Qanun Jinayat dengan menggunakan beberapa pendekatan. Pendekatan yang dapat dilakukan yaitu pendekatan religious dan moralitas, artinya pendekatan tersebut dapat memicu kesadaran masyarakat Kota Langsa bahwa Qanun Jinayat merupakan hasil dari perumusan yang diambil dari hukum Islam. Di sisi lain, perlu juga menciptakan moralitas penegak hukum untuk menumbuhkan kewibawaan para penegak Qanun Jinayat.

Selam ini qanun jinayat dirasakan masih lemah dalam perlindungan hukum bagi korban dan pelaku Qanun Jinayat. Rehabilitasi merupakan hak korban yang tertuang dalam qanun. Akan tetapi, tidak ada kejelasan hukum bagaimana prosedur dan sumber rehabilitasi yang akan diperoleh oleh korban, dampaknya aturan tentang rehabilitasi hanya sebatas norma. Dalam konteks perlindungan bagi pelaku pelanggaran qanun jinayat, perlu dilakukan kepastian hukum bahwa yang berwenang mengadili pelaku pelanggaran Qanun Jinayat adalah Peradilan Agama bukan Peradilan Gampong. 


\section{DAFTAR PUSTAKA}

Abbas, Syarizal. Maqashid Al-Syariah Dalam Hukum Jinayah Di Aceh. Banda Aceh: Dinas Syariat Islam Aceh, 2015.

Abubakar, Al Yasa. Syari'at Islam Di Provinsi Nanggroe Aceh Darussalam: Paradigma, Kebijakan, Dan Kegiatan. Banda Aceh: Dinas Syariat Islam, 2005.

Aditya, Zaka Firma, and Muhammad Reza Winata. "Rekonstruksi Hierarki Peraturan PerundangUndangan Di Indonesia (Reconstruction of The Hierarchy of Legislation In Indonesia)." Negara Hukum: Membangun Hukum untuk Keadilan dan Kesejahteraan 9, no. 1 (June 1, 2018). https://doi. org/10.22212/jnh.v9i1.976.

Ali, Fakhri. Kalla Dan Perdamaian Di Aceh. Jakarta: Lspeu Indonesia, 2008.

Amir Hamzah. Penyuluh Keagamaan Kota Langsa, wawancara, 13 Agustus 2019, n.d.

Anggriani, Jum. "Kedudukan Qanun Dalam Sistem Pemerintahan Daerah Dan Mekanisme Pengawasannya."Jurnal Hukum Ius Quia Iustum 18, no.3 (2011):320-35. https://doi.org/10.20885/ iustum.vol18.iss3.art2.

Asshiddiqie, Jimly. Perihal undang-undang. Jakarta: Rajawali Pers, 2010.

Darmawan. "Kedudukan Hukum Adat Dalam Otonomi Khusus." KANUN : Jurnal Ilmu Hukum, 2, 12 (2010): 334-48.

Djumala, Darmansjah. Soft Power Untuk Aceh: Resolusi Konflik Dan Politik Desentralisasi. Jakarta: PT Gramedia Pustaka Utama, 2013.

Friedman, Lawrence M. The Legal System: A Social Science Perspective. Translated by M. Khozim. Bandung: Nusa Media, 2013.

Hadjar, Ibnu. "Syari'at Islam dan Hukum Positif di Indonesia." Al-Mawarid 16 (2006). https://doi. org/10.20885/almawarid.vol16.art1.

Hooker, M. B. Adat Law in Modern Indonesia. East Asian Historical Monographs. Kuala Lumpur ; New York: Oxford University Press, 1978.

Husin, Taqwaddin. "Penyelesaian Sengketa/Perselisihan Secara Adat Gampong di Aceh." Kanun Jurnal Ilmu Hukum, no. 67 (2015): 22.

“Langsa Tangani 57 Kasus Jinayat - Serambi Indonesia.Html,” n.d.

Latif, Ibrahim. Kepala Dinas Syariat Islam Kota Langsa, Wawancara, 09 Agustus 2019, n.d.

Lubis, Zulkarnain, and Bakti Ritonga. Dasar-Dasar Hukum Acara Jinayah. Jakarta: Prenadamedia Group, 2016.

"Oknum Polisi Syariah Pemerkosa Tahanan Masuk Tahap Penyidikan - Nasional Tempo.Co.Html," n.d.

"Praktek Hukuman Cambuk Di Aceh Meningkat, Evaluasi Atas Qanun Jinayat Harus Dilakukan Pemerintah_ICJR.Html," n.d.

Rahardjo, Satjipto. Hukum Dan Perubahan Sosial: Suatu Tinjauan Teoretis Serta Pengalaman-Pengalaman Di Indonesia. Cet. 3. Yogyakarta: Genta Pub, 2009.

Soekanto, Soerjono. Faktor-Faktor Yang Mempengaruhi Penegakan Hukum. Jakarta: PT. Raja Grafindo Persada, 2008. 
. Kegunaan Sosiologi Hukum Bagi Kalangan Hukum. Bandung: PT. Citra Aditya Bakti, 1989.

Syariat Islam, Dinas. Himpunan Undang- Undang, Keputusan Presiden, Peraturan Daerah/ Qanun, Instruksi Gubernur Berkaitan Pelaksanaan Syariat Islam. Banda Aceh: Dinas Syariat Islam Provinsi NAD, 2006.

---. Hukum Jinayah Dan Hukum Acara Jinayah. Banda Aceh: Naskah Aceh, 2015.

Telaumbanua, Dalinama. “Undang-Undang Republik Indonesia Nomor 15 Tahun 2019 tentang Perubahan Atas Undang-Undang Nomor 12 Tahun 2011 tentang Pembentukan Peraturan Perundang-Undangan." Preprint. Open Science Framework, December 2, 2019. https://doi. org/10.31219/osf.io/xtdba.

Ubbe, Ahmad. "PERADILAN ADAT DAN KEADILAN RESTORATIF." Jurnal Rechts Vinding 2, no. 2 (2013): 15.

Usman, Atang Hermawan. "Kesadaran Hukum Masyarakat Dan Pemerintah Sebagai Faktor Tegaknya Negara Hukum Di Indonesia.” Jurnal Wawasan Hukum 30, no. 1 (2014): 28.

Yunus, Muhamud. Kamus Arab-Indonesia. Jakarta: PT Hidakarya Agung, 1989.

Zulkarnai. Ketua Majelis Pemusyawaratan Ulama Kota langsa, wawancara, 12 Agustus 2019, n.d. 